\title{
Inhalts-Verzeichniss.
}

\section{Einleitung. Seite}

Das Schachbrett und die Schachsteine . . 8 Rezeichnung des Brettes und der Züke nebst

Erklärung der Zeichen und Abkürzungen Erklärung der beim Spiele vorkommenden

Kunstrusdrïcke . . . . . . . . . 10

Regeln und Gesetze des Spieles. . . . . 15

Ueber den Werth der Steine . . . . . . 17

Gang und Anwendung der Steine . . . . 18

Beispicle des mittelalterlichen Spieles . . . 28

Chronologische Uebersicht der Schachliteratur 33

\section{Erstes Buch.}

Einleitende Bemerkungen . . . . . . . 68

\section{Erste Eröffnung.}

Das Springerspiel.

Absehn. I. Unregelmässige Vertheidigungs-

züge . . . . . . . . . . . . 73

Abschn. II. Gambit im Nachzuge . . . . 83

Abschn. III. Philidor's Vertheidigung. . 93

Abschn. IV. Russische Vertheidigung. . . 113

Alsschn. V. Schottisches Gambit . . . . 124

Abschn. VI. Ginoco piano. Italiänische

Partic . . . . . . . . . . . . 151

Abschn. VII. Gambit des Capitain Evans 171

Abschn. VIII. Zweispringerspiel im Nachzuge 213

- Abschn. IX. Springerspiel des Ruy Lo pez 229

Abschn. X. Lïuferbauer der Dame . . . 253

Anhang zum Springerspiel . . . . . . . 259

\section{- Zweite Eröffnung.}

\section{Das $L$ äuferspiel.}

Abschn. I. Verschiedene Angriffe im Läuferspiel . . . . . . . . . . . . 263 Abschn. II. Classischer Angriff im Läuferspiel 271 Abschn. III. Die Vertheidigung 2. Sg8-f6 . 281 Abschn. IV. 2. e7-c6 als zweiter Gegenzug 293 Abschn. V. Gambit in der Rückhand . . 293

\section{Dritte Eröffnung.}

Gemischte Spielanfänge.

Abschn. I. Spiel mit c2-c3, Mittelgambit u. Wiener Partie . . . . . . . . . 301
Abschn. II. u. III. Französische und Sicilianische Partic . . . . . . . . . 311

Abschn. IV. u. V. Gegenspiele der Springerund des Damenbauern. Anzüge mit den Läuferbauern . . . . . . . . . . 329 Abschn. VI. Damengambit und andere Anfänge mit 1. d2-d4 . . . . . . . 337

\section{Vierte Eröffnung.}

Nicht angenommenes und unregelmässiges Gambit des Königs . . . . . . . . 349

\section{Fünfte Eröffnung.}

Das Königsspringergambit.

Abschn. I. Unregelmässige Vertheidigung im angenommenen Springergambit . . . . 361

Abschn. Il Gambit des Cunningham . . 365 Abschn. III. Gambit des Allgaier u, Kieseritzky . . . . . . . . . . . 373

Abschn. IV. Unregelmässige Vertheidigung beim vierten Zuge des Springergambits. 403 Abschn. V. Gambit des Calabresen und des Philidor . . . . . . . . . 409 Abschn. VI. Gambit-Angriff ohne den Zug 5. h2-h4 . . . . . . . . . . . 421 Abschn. VII. Gambit des Salvio u. Cochrane. . . . . . . . . . . 431 Abschn. VIII. Opfer des Königsläufers . . 443 Abschn. IX. Gambit des Muzio . . . . 447

\section{Sechste Eröffnung.}

Abschn. I. Verschiedene Vertheidigungen gegen das Gambit des Königsläufers . . . . 465 Abschn. II. Gewöhnliche Vertheidigungen des Läufergambits . . . . . . . . . 481 Abschn. III. Eingeschränktes Länfergambit . 497

\section{Anhang zum ersten Buche.}

Abarten des Schach und Spiele mit Vorgaben 501

\section{Zweites Buch.}

Spicl-Endungen. 
Inhalts-Verzeichniss.

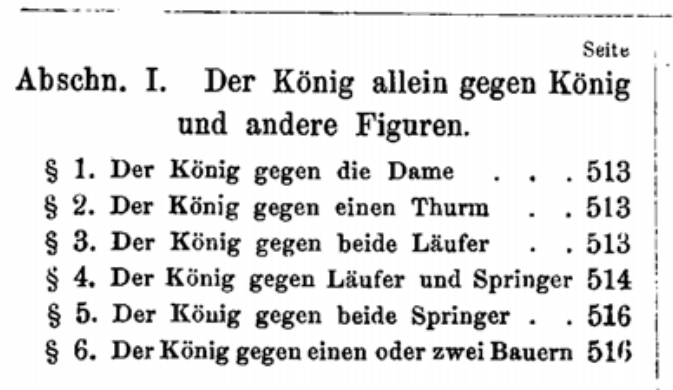

Abschn. II. Die Dame gegen verschiedene Figuren.

§ 1. König, Dame und verschiedene Steine gegen König, Dame und Steine . . 521

§ 2. König und Dame gegen König, Dame und Bauern . . . . . . . . . 523

§ 3. König u. Dame gegen König u. Thurm 525

§ 4. König und Dame gegen König, Thurın und Bauer . . . . . . . . . 527

§ 5. König und Dame gegen König und beide Thürme oder Thurm und Läufer . . 532

§ 6. König und Dame gegen König und beide Läufer . . . . . . . . . . . 533

§ 7. König und Dame gegen König und beide Springer . . . . . . . . . . 534

§ 8. König und Dame gegen König, Läufer und Springer. . . . . . . .541

§ 9. König und Dame gegen König u. Bauer 516

Abschn. III. Der T'hurm gegen verschiedene Figuren.

§ 1. König und Thurm gegen König und beide Thürme . . . . . . . . 550

§ 2. König u. Thurm gegen König, Thurm und Läufer . . . . . . . . . 551

§ 3. König u. Thurm gegen König, Thurm und Springer. . . . . . . . . 560

§ 4. König und Thurm gegen drei leichte Steine . . . . . . . . . . . 564

§ 5. König und Thurm gegen König, zwei Steine und Bauer . . . . . . . 565

§ 6. König u. Thurm gegen König, Thurm und Bauer . . . . . . . . . 566

§ 7. König und Thurm gegen König und Läufer . . . . . . . . . . . 571

§ 8. König, Thurm und Bauer gegen König und Läufer . . . . . . . . . 572

§ 9. König und Thurm gegen König und Springer . . . . . . . . . . 579
§ 10. König, Thurm und Bauer gegen König und Springer. . . . . . . . . 580

$\S$ 11. König und Thurm gegen König, Läufer und zwei Bauern . . . . . . . 581

$\S$ 12. König und Thurm gegen König, Springer und zwei Bauern... . . . 582

$\S$ 13. König u. Thurm gegen König u. Bauern 582

Abschn. IV. Der Läufer gegen verschiedene Figuren.

§ 1. Der König u. zwei Officiere gegen König und Springer oder Läufer . . . . 597

§ 2. Läufer von gleicher Farbe gegen einander . . . . . . . . . . . . 589

§ 3. Läufer von verschiedener Farbe gegen einander . . . . . . . . . . 591

§ 4. Läufer gegen Springer . . . . . 592

§ 5. Läufer gegen Bauern . . . . . . 595

Abschn. V. Der Springer gegen verschiedene Figuren.

$\S 1$. Beide Springer gegen König und Bauer 599

$\$ 2$. Springer und Bauern gegen Springer und Bauern . . . . . . . . . . 601

§ 3. König, Springer und Bauern gegen König und Bauern . . . . . . . 602

§ 4. König und Springer gegen König und Bauer . . . . . . . . . . 605

§ 5. König und Springer gegen König und Bauern. . . . . . . . . . . 605

§ 6. Anhang . . . . . . . . . . .608

Abschn. VI. Bauern gegen einander.

§ 1. König u. Bauer gegen König u. Bauer 610

§ 2. König und zwei Bauern gegen König und einen Bauern . . . . . . . . 611

§ 3. König und zwei Bauern gegen König und zwei Bauern . . . . . . . . 621

§ 4. König und zwei Bauern gegen König und drei Bauern . . . . . . . . 623

§ 5. Drei freie Bauern gegen den Köuig auf der einen und der andern Seite . . 624

$\S 6$. König und drei Bauern, welche nicht alle frei sind, gegen König und Bauern 629

$\S 7$. Beispiele, in denen beiderseitig vier oder mehr Bauern vorkommen . . . 633

Berichtigungen und Zusätze . . . . . . 637 